Hydrol. Earth Syst. Sci., 18, 1339-1348, 2014

www.hydrol-earth-syst-sci.net/18/1339/2014/

doi:10.5194/hess-18-1339-2014

() Author(s) 2014. CC Attribution 3.0 License.

\title{
Irrigation efficiency and water-policy implications for river basin resilience
}

\author{
C. A. Scott ${ }^{1}$, S. Vicuña ${ }^{2}$, I. Blanco-Gutiérrez ${ }^{3}$, F. Meza $^{2}$, and C. Varela-Ortega ${ }^{3}$ \\ ${ }^{1}$ University of Arizona, School of Geography \& Development, and Udall Center for Studies in Public Policy, \\ Tucson, Arizona, USA \\ ${ }^{2}$ Pontificia Universidad Católica de Chile, Centro Interdisciplinario de Cambio Global, Santiago, Chile \\ ${ }^{3}$ Universidad Politécnica de Madrid, Department of Agricultural Economics and Social Sciences, Madrid, Spain
}

Correspondence to: C. A. Scott (cascott@email.arizona.edu)

Received: 22 June 2013 - Published in Hydrol. Earth Syst. Sci. Discuss.: 29 July 2013

Revised: 11 February 2014 - Accepted: 25 February 2014 - Published: 7 April 2014

\begin{abstract}
Rising demand for food, fiber, and biofuels drives expanding irrigation withdrawals from surface water and groundwater. Irrigation efficiency and water savings have become watchwords in response to climate-induced hydrological variability, increasing freshwater demand for other uses including ecosystem water needs, and low economic productivity of irrigation compared to most other uses. We identify three classes of unintended consequences, presented here as paradoxes. Ever-tighter cycling of water has been shown to increase resource use, an example of the efficiency paradox. In the absence of effective policy to constrain irrigatedarea expansion using "saved water", efficiency can aggravate scarcity, deteriorate resource quality, and impair river basin resilience through loss of flexibility and redundancy. Water scarcity and salinity effects in the lower reaches of basins (symptomatic of the scale paradox) may partly be offset over the short-term through groundwater pumping or increasing surface water storage capacity. However, declining ecological flows and increasing salinity have important implications for riparian and estuarine ecosystems and for non-irrigation human uses of water including urban supply and energy generation, examples of the sectoral paradox. This paper briefly considers three regional contexts with broadly similar climatic and water-resource conditions - central Chile, southwestern US, and south-central Spain - where irrigation efficiency directly influences basin resilience. The comparison leads to more generic insights on water policy in relation to irrigation efficiency and emerging or overdue needs for environmental protection.
\end{abstract}

\section{Introduction}

Irrigation in river basins has been widely examined from a range of perspectives including crop water productivity (Molden et al. 2010), water conservation (Perry, 2011; Santos Pereira et al., 2012), and socio-economic development (Molle and Wester 2009). Undoubtedly, irrigation expansion has led to major gains in agricultural production and food security (Falkenmark and Lannerstad, 2005), crop diversification, and profitability. As the highest-volume use of water for human purposes globally, irrigation has profound implications for other uses (urban and industrial supply, hydropower, and thermoelectric generation) especially under the dual processes of human-induced water scarcity and climate change and variability (Lankford, 2013). To buffer against scarce and variable surface water flows, societies appropriate basin water resources using storage reservoirs, groundwater pumps, and reuse schemes that capture excess diversions (urban wastewater and irrigation return flows). The result is that riparian ecosystems are experiencing unintended consequences of direct, often irreversible, impacts of water appropriation. In basins around the world, infrastructure expansion continues, often resulting in full surface diversion and groundwater depletion; thus, instream flows cross critical thresholds leading to intermittency, loss of ecosystem services, and regime shifts as natural riparian systems become social-hydraulic systems. In the latter, intensive water management seeks to allocate water saved through efficiency to enhance multiple uses of water and increase water productivity; as a result, efficiency often results in an expansion 
of irrigated area, instead of reallocation to other uses. Less frequently do policies effectively constrain or limit agricultural expansion using saved water, an important challenge of the efficiency paradox evaluated below. Thus, irrigation efficiency is of emblematic concern to resource use and management in Anthropocene - the subject of the present HESS special issue. This paper examines the assumptions, mechanisms, contradictions, and conditions required for water savings through irrigation efficiency. Three cases from central Chile, southwestern US, and south-central Spain are compared with illustrative examples of the efficiency, sectoral and scale paradoxes posited in the abstract. Furthermore, lessons learned for a broader set of conditions in irrigationintensive, heavily appropriated river basins worldwide are presented and discussed.

We take as our point of conceptual departure the policy implications of irrigation efficiency raised by Lankford (2012), who builds on the work of numerous others, many of whom we cite in this paper. Of particular concern is whether and under which conditions "basin allocation irrigation efficiency" drives water depletion and attendant water quality deterioration. Under purely surface-water diversion, systems of irrigation used principally by livelihood-dependent smallholders, Lankford's "socialised localised irrigation efficiency" linking upstream and downstream users along a canal provides explanatory insight on return-flow recovery. Building on this approach refined by Lankford (2013), we suggest two conditions change the within-basin configurations of water use: recovery of "lost water" and upstream-downstream positionality. First, technology alters the classical return-flow cycle in river basins, e.g., pumping of groundwater (which intercepts water that might have become return flow) and lift irrigation from gravity canals. More generally, in the case of inter-basin transfers, pumping increasingly challenges the basin paradigm (an instance of the scale paradox). Additionally, pumped irrigation alters water appropriation, and, importantly, it also alters profit motives behind investments in efficiency based on the rationale of localized capture of "saved water" that is an important driver of area expansion leading to depletion (the central efficiency paradox challenge addressed in this paper). Second, institutions provide backing for (or may inhibit) irrigation expansion or agriculture-urban water transfers. Water rights represent an important category of institutional arrangements; in the basins we examine here, prevailing systems of rights extend ownership over "saved water" and thereby justify technology investments.

\section{Key concepts}

\subsection{Coupled human-water systems}

There is growing recognition of the interconnected nature of socio-hydrological and agro-ecological systems. Water-resource impacts include scarcity and water-quality degradation that occur across sectors. For example, cities influence agriculture through priority appropriation and wastewater flows that have impacts on downstream water quantity and water quality for agriculture, while irrigation and food security may provide the public rationale to invest in infrastructure that in turn impacts cities and ecosystems. Integrated river basin management and multiple-use systems that link uses and users of water within the river basin spatial domain, accounting for third-party effects, are tested approaches with significant backing in concept and practice (Jaspers, 2003; Lankford et al., 2007). Molle and Wester (2009) describe the evolution of such inter-relations as river basin trajectories, in which large hydraulic infrastructure projects at an early stage of basin development are commonly superseded by local, often private investment in efficiency improvements particularly in irrigation. The conditions that help explain the transition from hardpath, technology-oriented basin-development approaches to soft-path, learning-oriented adaptive approaches are closely linked to technology and institutions. Both infrastructureand learning-based phases have important implications for water availability to meet human and ecosystem needs.

The coupled, mutually inter-dependent nature of socioagro-ecological systems means that tradeoffs are inevitable; yet researchers and managers focused on subsystem components neglect tradeoffs, or - if they do recognize them - attempts are made to compartmentalize or isolate tradeoffs. Thus, policy-making can produce unintended consequences and lead to paradoxical outcomes, which we characterize in this paper as the efficiency paradox (leading to resource depletion), the scale paradox (spatially and temporally displaced impacts), and the sectoral paradox (particularly related to the water-energy nexus). Neglecting the interrelations of higher-order socio-hydrological systems, therefore, can threaten the stability and resilience of systems.

\subsection{Tradeoffs threaten river basin resilience}

Fixed volumetric or percentage-flow allocations of water for instream human uses (hydropower, navigation, fisheries, and recreation) and off-stream uses (domestic, irrigation and industrial) have tended to characterize basin management approaches. This belies the complexity imposed by hydroclimatic variability and uncertain human demands. Nevertheless, in water-scarce regions, ecosystem water needs tend to be viewed as a "residual demand" in allocation frameworks (i.e., only once human water appropriation has been met are environmental flows recognized). Thus, river basins as interconnected social-ecological systems respond to a series of internal and external drivers that vary over time. Basins are resilient in the degree to which they can absorb disturbances and continue to provide services and functionality to human and ecological communities alike.

Flexibility, capacity to absorb disturbance, and redundancy are features of social-ecological resilience that, when 
applied to river basin systems, provide explanatory insight on recovery from crises such as extended drought (Scott and Buechler, 2013; Rockström, 2003). Specifically for irrigation, groundwater "incidental" recharge from inefficient canals (Foster and Perry, 2010) is an important source of water that may indeed have higher value in economic and buffering terms than the primary surface water source. Such buffering capacity may be degraded in the basin trajectory currently underway in many "closed" (fully developed, overallocated) river basins where management is centered on recapture of "losses" through efficiency, which we show to be paradoxical in the sense that water may simply be redirected physically to other sectoral uses; for example, agricultural efficiency savings may be captured by urban supply. Basin resilience in these terms can be enhanced through adaptive management to maintain or expand flexibility while preserving redundancy (Scott et al., 2013). Flexibility in adaptive management is akin to redundancy, or "lacunae" (Ulanowicz et al., 2009), in ecological terms.

In river basins, upstream-downstream positionality matters; that is, options to recapture losses can be contingent on location with respect to the ocean or another "salt sink". As we will show, the Limarí Basin in Chile is different from Imperial Valley (drains into the highly saline Salton Sea). Furthermore, transfers of multiple types we consider - ruralurban and above-below canal - actually reconfigure basins in hydrological and water-use terms; this is an example of the scale paradox we posed above. These dynamics also alter which users or ecosystems are able to retain flexibility and which ones experience the impacts of efficiency-driven scarcity and quality degradation.

\subsection{Irrigation efficiency tradeoffs}

A particular type of tradeoff occurs in irrigation systems. Here we address the following question: are tradeoffs inevitable among irrigation-efficiency interventions, ecosystem services, and agricultural production? If so, what are the policy frameworks that encourage or discourage efficiency, and in turn, mediate impacts on river basin resilience? We understand tradeoffs in terms of zero-sum games; that is, irrigation losses or return flows that support key basin ecological functions must not simply be captured by increased human water appropriation. Thus, our intent is to explore various dimensions of the often-neglected tradeoffs between irrigation efficiency (with productivity enhancements) and water for ecosystem processes (that in turn lead to the provision of ecosystem services). Water scarcity, irrigation (in-)efficiency, losses/savings, and water productivity in physical and economic terms have been extensively characterized (Lankford, 2013; Molden et al., 2010; Perry, 2011; Falkenmark and Lannerstad, 2005). Our conceptual approach (see Fig. 1) draws from the definitions posed by Perry (2011, p. 1841). In irrigation, the consumed fraction (evaporation and transpiration) is comprised of beneficial consumption shown in

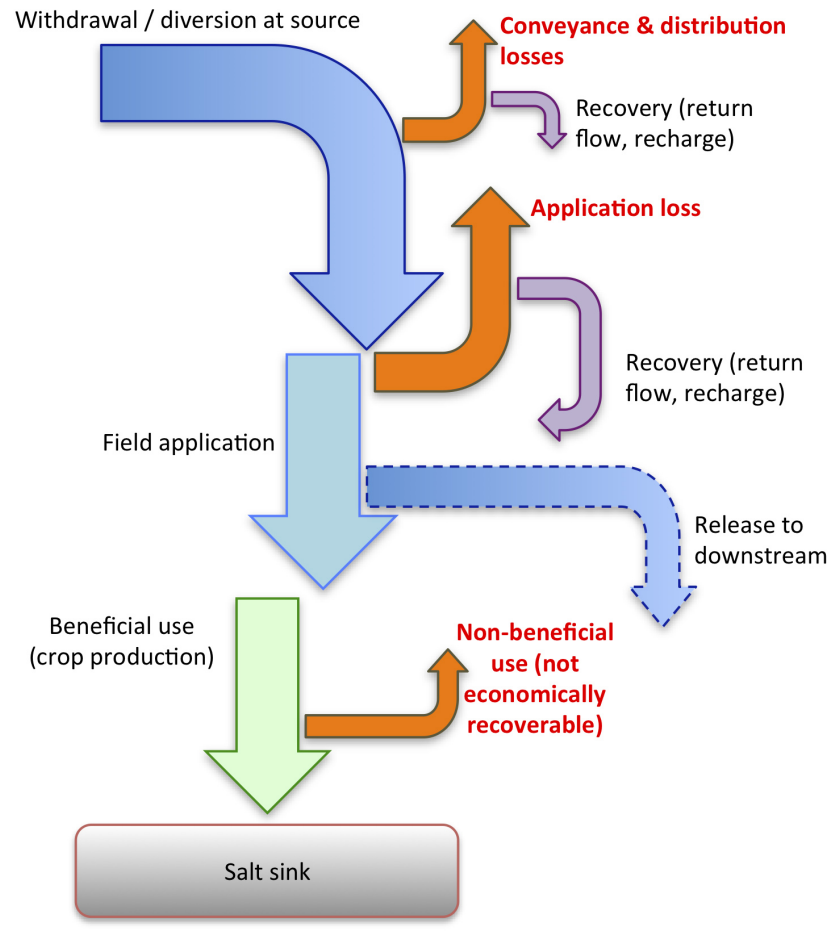

Fig. 1. Irrigation efficiency, loss/depletion, and recovery.

the large vertical arrows (e.g., water transpired by an irrigated crop) that can lead to increased productivity per unit of water and often of land, and non-beneficial consumption (water transpired by weeds or evaporated from waterlogged land). Additionally, the non-consumed fraction is comprised of a recoverable fraction shown in purple (return flows serving as downstream irrigation sources or aquifer recharge) and a non-recoverable fraction as the residual flow (to a saline sink such as the sea or water polluted beyond useable limits). Perry (2011), Whittlesey (2003), and Ward and Pulido (2008) identified the potential consequences of irrigation improvement resulting in reduced water availability elsewhere or over time as well as the implications of improved crop water deliveries for productivity. Thus, neglecting the coupled nature of socio-hydrological systems threatens the stability and resilience of systems. The central conceptual assertion of this paper is that irrigation-ecosystem tradeoffs exist and must be accounted for; these processes are exemplified by the paradoxical implications of irrigation efficiency for basin resilience as we explore through case examples below.

Agronomists define irrigation efficiency as fraction of the water applied that is stored in the soil and becomes available to satisfy crop water requirements (evapotranspiration beneficial use). Irrigation is then planned (frequency and operation time) considering available water content in the soil, crop evapotranspiration and delivery efficiency. Management practices such as the use of variable ("surge") flows for furrow irrigation, field-scale operation during hours of 

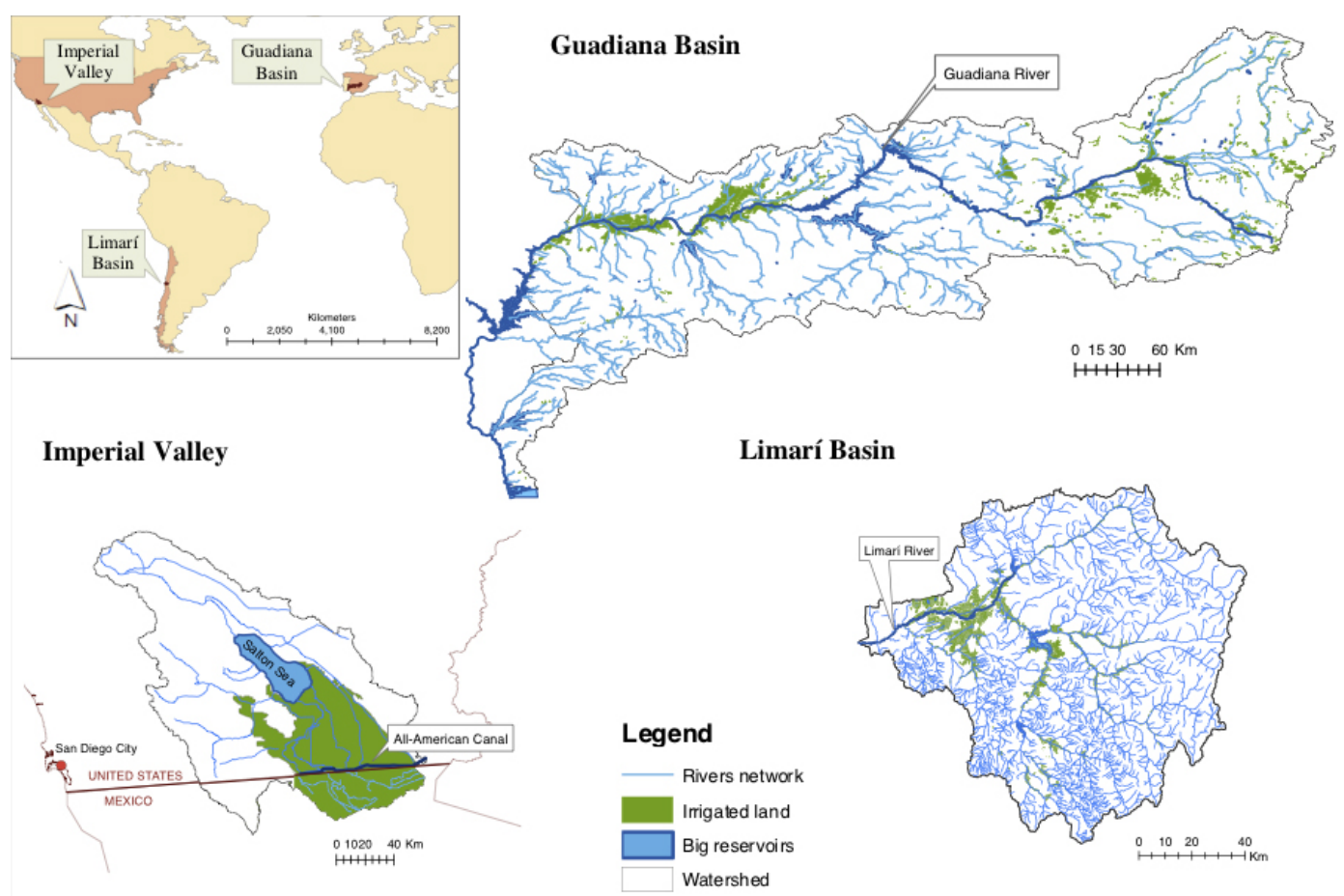

Limarí Basin

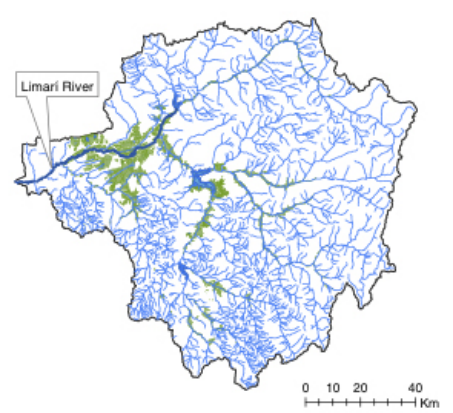

Fig. 2. Basin locator maps.

low atmospheric water demand, and field leveling can substantially increase irrigation efficiency and produce positive effects on crop productivity. However, overall systems efficiency gains through operations alone can be bounded, and further improvements in efficiency are achieved only through introduction of new in-field irrigation technologies.

Changes in efficiency at the field-level require an investment in technology, such as pressurized drip irrigation, which is not always possible due to financial constraints, especially in small-scale agriculture. In addition we observe that in places where the price of water is low or null (relative abundance) there are few incentives to invest in efficiency improvements. Therefore, we usually find low-efficiency systems (such as flood irrigation) in places where there is unrestricted water supply and/or frequently associated with lowvalue crops.

The focus on water applied has proven to be an obstacle for farmers considering strategies to improve yield and profit under water-limited conditions. Water use efficiency (a concept often used in eco-physiology) measured as productivity (yield per unit water transpired) needs to be expanded to related measures like crop yield per unit water applied, which has implications for management practices to make strategic decisions (such as water allocation) and can also be of help to analyze the impact of controlled deficit irrigation.

\section{Case examples}

We explore the tradeoffs among irrigation, efficiency, ecosystem services, and agricultural production with reference to river basin resilience for the three basins where irrigation water use is recognized to drive water scarcity and where efficiency improvements that are underway, or have recently been implemented, hold potential to enhance river basin resilience. These are the Limarí Basin in Chile, the Imperial Valley in the US, and the Guadiana Basin in Spain (see Fig. 2). The basins also represent different dimensions of the three paradoxes (see Table 1) and therefore serve to illustrate our conceptual approach.

\subsection{Limarí Basin}

The Limarí Basin is located in semi-arid central Chile with an average precipitation of slightly over $100 \mathrm{~mm}$ heavily concentrated in winter months as is predominant in the Mediterranean climate that dominates this region in Chile (see Table 1). As is common in this region, this $12000 \mathrm{~km}^{2}$ basin has a highly variable snowmelt-dominated hydrology. The coefficient of variation of annual streamflows at the headwaters of the basin is 1.22 with $85 \%$ of years presenting an annual volume of water of only $20 \%$ of the historic average. This high variability, combined with the ideal climatic conditions for the development of a more intensified and export-oriented agriculture, motivated the construction of the Paloma Reservoir, which was finished in 1968. This reservoir was designed 
Table 1. Basin socio-hydrological comparison.

\begin{tabular}{|c|c|c|c|c|c|c|c|c|}
\hline & \multirow{2}{*}{$\begin{array}{l}\text { Annual } \\
\text { precipitation } \\
(\mathrm{mm})\end{array}$} & \multirow{2}{*}{$\begin{array}{l}\text { Winter } \\
\text { precipitation } \\
(\mathrm{mm})\end{array}$} & \multirow{2}{*}{$\begin{array}{l}\text { Average } \\
\text { temperature } \\
\left({ }^{\circ} \mathrm{C}\right)\end{array}$} & \multirow{2}{*}{$\begin{array}{l}\text { Total } \\
\text { area } \\
\left(\mathrm{km}^{2}\right)\end{array}$} & \multicolumn{2}{|c|}{$\begin{array}{c}\text { Evolution of area under } \\
\text { irrigation (ha) }\end{array}$} & \multicolumn{2}{|c|}{ Irrigation method ( $\%$ area) } \\
\hline & & & & & 1975 & 2007 & 1975 & 2007 \\
\hline Imperial Valley* & 71 & 43 & 23 & 11608 & 183248 & 151829 & Furrow (94\%) & $\begin{array}{l}\text { Furrow/border } \\
(85 \%), \\
\text { Sprinkler }(15 \%)\end{array}$ \\
\hline \multirow[t]{4}{*}{ Limarí Basin** } & 109 & 96 & 17 & 12000 & 38000 & 64000 & Flood $(100 \%)$ & $\begin{array}{l}\text { Flood (40\%), } \\
\text { Drip (60\%) }\end{array}$ \\
\hline & \multicolumn{8}{|c|}{ Evolution of crop mix } \\
\hline & \multicolumn{4}{|c|}{1975} & \multicolumn{3}{|c|}{2007} & \\
\hline & Cereals & Vegetables & $\begin{array}{l}\text { Orchards } \\
\text { (vineyards) }\end{array}$ & $\begin{array}{l}\text { Pasture and } \\
\text { other }\end{array}$ & Cereals & Vegetables & $\begin{array}{l}\text { Orchards } \\
\text { (vineyards) }\end{array}$ & $\begin{array}{l}\text { Pasture and } \\
\text { other }\end{array}$ \\
\hline \multirow[t]{3}{*}{ Limarí Basin** } & $51 \%$ & $18 \%$ & $17 \%$ & $14 \%$ & $3 \%$ & $8 \%$ & $48 \%$ & $40 \%$ \\
\hline & \multicolumn{8}{|c|}{ Comparison of paradoxes } \\
\hline & $\begin{array}{l}\text { Improved } \\
\text { efficiency }\end{array}$ & $\begin{array}{l}\text { Improved } \\
\text { crop } \\
\text { productivity }\end{array}$ & $\begin{array}{l}\text { Heightened } \\
\text { water use } \\
\text { (efficiency } \\
\text { paradox) }\end{array}$ & $\begin{array}{l}\text { Out of basin } \\
\text { transfer }\end{array}$ & $\begin{array}{l}\text { Non- } \\
\text { irrigation } \\
\text { water use } \\
\text { (sectoral } \\
\text { paradox) }\end{array}$ & $\begin{array}{l}\text { Upstream } \\
\text { shift of water } \\
\text { use }\end{array}$ & $\begin{array}{l}\text { Downstream } \\
\text { impact }\end{array}$ & $\begin{array}{l}\text { Depletion (scale } \\
\text { paradox) }\end{array}$ \\
\hline Guadiana Basin & High & High & Yes & No, limited & Low/medium & Yes & High & Yes \\
\hline Imperial Valley & Medium & Medium & Yes & Yes, major & High, driver & Partially & High & Yes \\
\hline Limarí Basin & High & High & Yes & No, limited & Low/medium & No & Medium & Medium \\
\hline
\end{tabular}

* 1974 and 2007 Census, respectively; ** 1975 from Paloma Reservoir design; 2007 from Agriculture and Livestock Census.

to store 740 million $\mathrm{m}^{3}$ (almost twice the annual average flow) completing already existing 250 million $\mathrm{m}^{3}$ of storage capacity in two other reservoirs and creating a complex system of irrigation channels that connects these reservoirs. Before this system of reservoirs was completed in the late 1970s, irrigated land in the valley floor amounted roughly to 40000 ha. According to the last Agriculture Census that figure has increased in 30 years to more than 60000 ha. Irrigation technology on the other hand has moved from a system dominated by flood irrigation to more than $60 \%$ covered by high-efficiency drip irrigation technology (see Table 1).

The prevailing water rights system gives complete ownership to water independent of land ownership and final use of water (Bauer, 2004) and thus fosters the irrigation efficiency paradox in which "saved water" is used to increase acreage. This economic driver translates into a scenario today where high-value crops like vineyards and orchards dominate a crop mix that was previously dominated by low-value crops such as cereals (see Table 1). This change in crop mix has been enhanced by subsidies given by the public sector through regulations designed to promote the development of high irrigation efficiency and irrigation supply reliability. The extended irrigated acreage that has been possible thanks to this mix of water and irrigation policies should come as no surprise considering that the subsidy is granted to applicants who can demonstrate that there will be an extension of irrigated land with the aid of improved irrigation efficiency (Ley de Fomento al Riego No. 18.450).

The extension in irrigated land, especially with permanent crops, has reduced the ability in the basin to withstand sustained drought episodes (such as the one confronting the basin at the time this manuscript was being written) without the system being able to supply the permanent crop water demand. This results in cutting trees and leaving vineyards out of production (personal communication, September 2013 with Manuel Muñoz, Administrator of Junta de Vigilancia Rio Limarí). This threatens to decrease resilience and adaptive capacity and could affect the long-term sustainability of agriculture in this basin considering droughts should become more prominent according to climate change projections. Global circulation models based on greenhouse-gas emission scenarios consistently show a reduction in precipitation on the order of $10 \%$ for the period 2010-2040 (Vicuna et al., 2011, 2012).

The result of an apparent increase in total use of water (efficiency paradox) reflects also on the small amount of water 


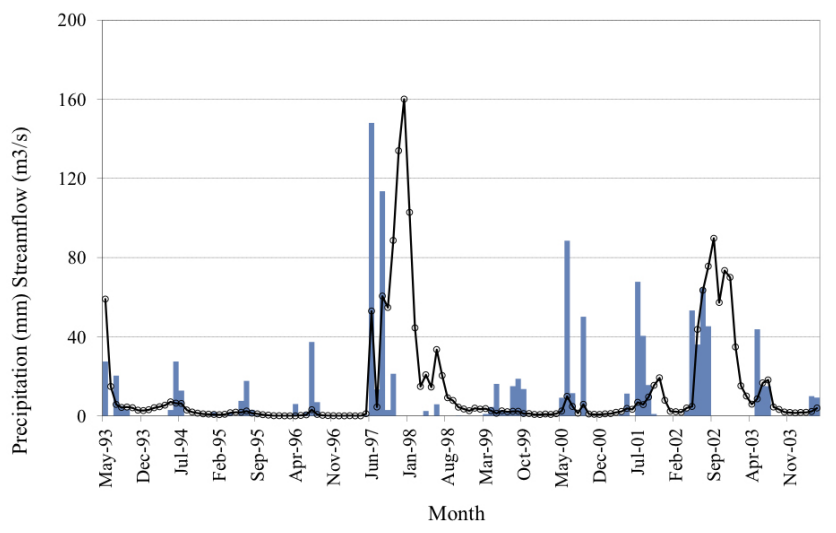

Fig. 3. Limarí Basin - comparison of monthly streamflow (panAmerican gauge station) and precipitation (blue bars) (Ovalle station).

flowing at the outlet of the basin (scale paradox) as can be seen in Fig. 3, which compares monthly streamflow before the basin reaches the ocean with monthly precipitation at the valley floor. The figure shows that only during periods of significant precipitation (e.g., 1997 and 2002) does monthly streamflow exceed $5 \mathrm{~m}^{3} \mathrm{~s}^{-1}$. Comparing the upper and lower portions of the river, we find that this $5 \mathrm{~m}^{3} \mathrm{~s}^{-1}$ threshold is exceeded only $35 \%$ of the time in the lower section, whereas in the upper section (where all available flow has not yet materialized) it is exceeded $65 \%$ of the time. It is important to note that the recorded information does not allow us to infer the situation prior to the increases in irrigated acreage and irrigation efficiency, but we can conjecture that streamflow was higher and less variable earlier in the trajectory of the basin.

\subsection{Imperial Valley}

Hydrologically part of the New River basin, the extreme aridity (71 $\mathrm{mm}$ annual precipitation) of the Imperial Valley in California means that surface water is essentially all irrigation (and return flows including urban wastewater) that comes via conveyance canal from the Colorado River basin. By contrast with the Limarí case, increased efficiency in the Imperial Valley has been pursued largely with the objective of transferring water out of the basin for urban uses (IID, 2007) - an example of the sectoral paradox, with a resulting decline in local within-basin resilience including reductions in aquifer recharge that had previously resulted from seepage across the US-Mexico border (Maganda, 2005). Securing water for environmental conservation in the binational region is complicated by high urban demand, rising water prices, and salinity constraints of using wastewater and irrigation return flows (Medellín-Azuara et al., 2007).

A cornerstone of pursuing irrigation efficiency improvements in Imperial Valley and the lining of the All-American Canal has been to transfer "saved" water to urban uses in

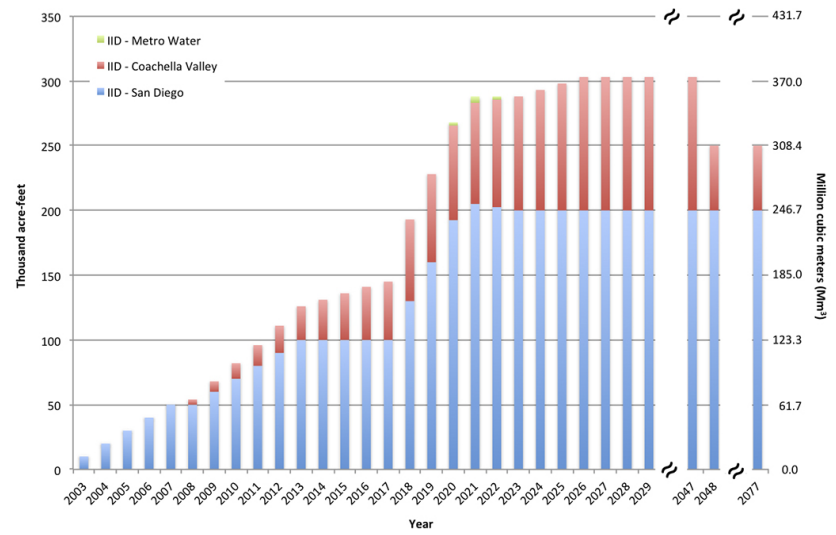

Fig. 4. Phased transfer of water from Imperial Irrigation District to urban uses, 2003-2077. Source: http://www.sdcwa.org/ quantification-settlement-agreement.

San Diego - outside the Imperial Valley basin. In the 1990s San Diego experienced dramatic reductions in alternative sources of supply from the Metropolitan Water District resulting from drought conditions. In 2003 the Imperial Irrigation District (IID) signed the Quantification Settlement Agreement (QSA) to initiate phased water transfers to San Diego and Coachella Valley. As shown in Fig. 4, by 2026 this would be increased to 303000 acre-feet $\left(374 \mathrm{Mm}^{3}\right)$ annually, of which 130000 acre-feet $\left(160 \mathrm{Mm}^{3}\right)$ had to come from on-farm efficiency improvements. IID's annual entitlement is 3.1 million acre-feet $\left(3826 \mathrm{Mm}^{3}\right)$. IID (2007) estimated that canal lining represented the lowest-cost method of water conservation (USD 13-15 acre-foot, equivalent to USD 10 500$12200 / \mathrm{Mm}^{3}$ ). On-farm water conservation to be achieved through voluntary adoption of sprinkler irrigation and other efficiency improvements would be the most expensive, in excess of the USD 300/acre-foot (USD 243 200/ $\mathrm{Mm}^{3}$ ) "target" cost set for the transfer arrangement in the QSA. Additionally, automated monitoring and control systems costing approximately USD 160/acre-foot (USD $129700 / \mathrm{Mm}^{3}$ ) were identified to have potential to save in excess of half a million acre-feet (almost $700000 \mathrm{Mm}^{3}$ ) of canal spillage and tailwater discharges, which ultimately flow to the Salton Sea. The price structure was subsequently renegotiated in 2009 with the result that IID forecast its 2016 annual revenues to be in excess of USD 62 million based on an agreed transfer of 100000 acre-feet at USD 624/acre-foot (IID, 2009). However, several of the QSA provisions passing certain environmental mitigation costs to California taxpayers were challenged in court.

It should be noted that the Salton Sea is below sea level and was created in 1905 by the accidental rupturing of Imperial Valley irrigation canals. It covers an average of $1360 \mathrm{~km}^{2}$ and receives inflow of 1.36 million acre-feet $\left(1.68 \mathrm{~km}^{3}\right)$, which is declining as a result of irrigation efficiency and water transfers coupled with climate change (Case III et al., 2013). 


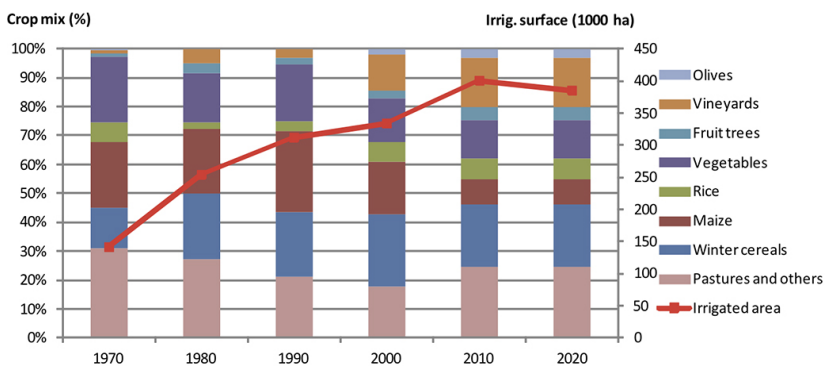

Fig. 5. Increase of irrigated area and change in crop mix in the Guadiana Basin, 1970 to 2010. Source: based on statistical data from CHG (2013) and MAGRAMA (2013).

Salinity levels, already $25 \%$ greater than that of the Pacific Ocean, are increasing with the result that only tilapia fish are expected to survive. The Salton Sea is an important resting stop for birds on the Pacific flyway, with over 400 species documented. Other ecosystem services include amenity value for adjoining real estate development. Thus, ecosystem impacts of efficiency and transfer options are significant.

\subsection{Guadiana Basin}

The Guadiana River basin $\left(67147 \mathrm{~km}^{2}\right)$ is a large transnational basin shared by Spain (83\%) and Portugal (17\%). The analysis presented here refers to the Spanish portion only, with data from Ciudad Real and Badajoz municipalities representing $75 \%$ of the total area. The basin has a predominantly continental Mediterranean climate with annual average precipitation of $521 \mathrm{~mm}$ year $^{-1}$ being greatly exceeded by annual average potential evapotranspiration of $983 \mathrm{~mm}$ year $^{-1}$ (see Table 1 ).

As other semi-arid basins, the Guadiana is characterized by intensive irrigation use. Agriculture accounts for $90 \%$ of all water consumption, compared to $7 \%$ for domestic use and $3 \%$ for industry (CHG, 2013). Irrigation development in the region started in the early 1960s and 1970s with the creation of reservoirs and distribution network infrastructure, and in response to technological advances including new irrigation and well-drilling techniques. Significant area expansion was driven by uncontrolled groundwater exploitation (Llamas and Martínez-Santos, 2006) and fueled mainly by economic incentives linked to the European Common Agricultural Policy (CAP), which Spain adopted in 1986 (VarelaOrtega, 2011). During the 1980s and 1990s, the establishment of production-based subsidies from the CAP encouraged the expansion of irrigated areas and favored the production of high-yielding water-intensive cereals (e.g., maize, rice, barley, and wheat). In recent years and after several policy reforms (EC, 2003, 2009), CAP subsidies have been progressively decoupled from production, making agriculture more competitive and market oriented. As seen in Fig. 5, high-value crops with low water requirements and a high

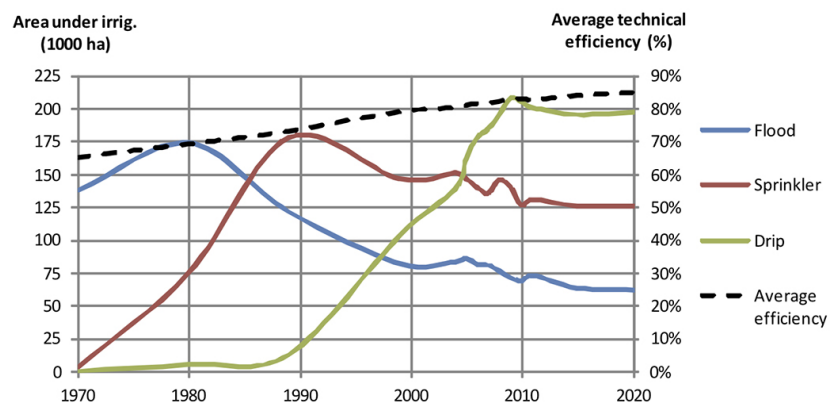

Fig. 6. Change in on-farm irrigation methods and estimated water use efficiency in the Guadiana Basin, 1970 to 2010. Source: based on statistical data from CHG (2013), INE (2009), and MAGRAMA (2012).

impact in labor such as vineyards, olives trees, fruit trees (peach, plum, pear), and vegetables (tomato, melon) are the current trend.

The Guadiana Basin is characterized as a rural territory with low population density where water and irrigation have for decades been seen as the main route to modernize the region and prevent land abandonment and depopulation. In the last forty years, the area in irrigation had expanded by $300 \%$ (from 140730 ha in 1970 to 400431 ha in 2010; see Fig. 5). Irrigation development has increased agricultural production and crop diversification, enhancing income generation and favoring labor creation in rural areas (Varela-Ortega, 2011). However, it has been achieved at the expense of negative environmental impacts, namely alteration of natural hydraulic river regimes, reduction of in-stream flow volumes, disappearance of riparian vegetation, over-pumping of fragile aquifers, and the degradation of internationally protected water-dependent natural spaces (e.g., Tablas de Daimiel National Park in the upper part of the basin, and Sites of Community Importance and Special Protection Areas in the middle and lower part of the basin), which have reduced the resilience of the socio-ecological system in the river basin (Blanco-Gutiérrez et al., 2011, 2013). These and the trends shown in Fig. 6 represent examples of the efficiency and scale paradoxes. In 1987, La Mancha Occidental and Campo de Montiel aquifers, the largest and most important in the basin, were legally declared overexploited with strict regulatory measures applied to both public and private water users. All water resources in Spain have been public property since 1986, when the Spanish Water Act 29/1985 made groundwater ownership public. In addition to surface water users, groundwater users were granted administrative concessions of water use rights defined by specific water allotments. Yet, those who wished to remain in the private property regime were allowed to do so. Therefore, public and private regimes still coexist.

In 1991, drilling new wells or deepening the existing ones was prohibited and the entitled historical water rights of 
irrigators were cut by half due to the imposition of a strict water quota regime (Varela-Ortega et al., 2011). This situation encouraged farmers to adopt modern water-saving technologies and to replace traditional surface irrigation methods with low-volume irrigation techniques. In $2000,75 \%$ of the irrigated land (almost $250000 \mathrm{ha}$ ) was under pressurized irrigation systems, with center pivots being the most extensive (see Fig. 6). These trends demonstrate tradeoffs associated with the efficiency paradox.

Irrigation modernization accelerated in the 2000s through the implementation of an ambitious nation-wide irrigation modernization program, the Spanish National Irrigation Plan (2002-2008), which was revitalized with a second plan, the Emergency Plan for the Modernization of Irrigation (20062008) after the extreme drought of 2004-2005. Modernization was based on the improvement of storage facilities, lining and piping of old canals, and on the development of new irrigation and drainage systems, including the adoption of on-farm modern irrigation technologies. In total, $€ 600$ million were invested in the Guadiana Basin, and notably in the middle part of the basin, where 185000 ha (about $45 \%$ of the total irrigated land) were completely refurbished.

According to AEVAL (2010) and López-Gunn et al. (2012), the resulting water savings obtained from increasing technical irrigation efficiency in the Guadiana region ( $243 \mathrm{Mm}^{3}$ year $^{-1}$ from 2002 to 2006 and $94 \mathrm{Mm}^{3}$ year $^{-1}$ from 2006 to 2008) have been re-used to expand the irrigated area (see Fig. 5), increase yields and therefore evapotranspiration of existing crops, as well as to support a higher value and more diversified agricultural production, increasing overall consumptive use (efficiency paradox). The main rationale behind it is that irrigation modernization has not been accompanied by a reduction in the amount of water designated in concessions (water allotments have not changed in the last 10 years being of $7500 \mathrm{~m}^{3} \mathrm{ha}^{-1}$ for surface irrigators, and $4200 \mathrm{~m}^{3} \mathrm{ha}^{-1}$ for groundwater irrigators except for those located in overexploited aquifers that are limited to $2000 \mathrm{~m}^{3} \mathrm{ha}^{-1}$ ). This, together with the lack of stringent limits in irrigation expansion and the low price of water, has offset the intended impact of the irrigation modernization process in the Guadiana Basin and in Spain, which is to save water to alleviate the consequences of cyclical droughts and to free water resources for river flows and the natural habitats they provide in order to achieve the environmental objectives of the European Water Framework Directive.

\section{Conclusions}

Irrigation improvements can present unintended consequences when broader scales and multiple uses of water are considered (Lankford, 2013). In a process we term the efficiency paradox, water "saved" leads to increased use of water through irrigation expansion, as shown in the Limarí and Guadiana cases. In a related but distinct process we term the scale paradox - water "loss" upstream serves as supply downstream particularly for ecosystems, as observed by Perry (2011) and shown here for all three cases, Limarí, Imperial Valley-Salton Sea, and Guadiana. The scale paradox may also apply to downstream irrigators, as evidenced in the Imperial Valley case in the reduction of cross-border seepage flows to Mexico resulting from the lining of the AllAmerican Canal. A third process involves the sectoral para$d o x$, in which savings are reallocated to alternative uses (e.g., water transferred from Imperial Valley to San Diego city).

Of broader relevance beyond the specific cases considered in this paper, irrigation efficiency without caps on use - or limits to area expansion - may increase production (and productivity), but it undermines the resilience of basins under conditions of water scarcity. Eliminating slack in the system through stringent water conservation and allocation of savings to new uses can result in the "hardening" of demand that will entail crop loss or irrigated area restrictions under future conditions of water shortage. This is particularly true for the integrated management of water and land to meet ecological flow requirements under changing climate scenarios. Thus, a basin's capacity to meet human and ecosystem water needs often follows a moving target.

Policy mechanisms to reserve surplus water in the reservoir or aquifer instead of expanding irrigation include regulated controls on irrigated area, price incentives, and provision of information to support farmer and irrigation district decision-making to better adapt to future contingencies. The latter represents a case of "socialised localised irrigation efficiency" (Lankford, 2012). Investing public resources to anticipate and offset the effects of water scarcity ex ante represents a more effective adaptive response to drought than ex post mitigation efforts.

Acknowledgements. Partial funding support for this research was provided by the Inter-American Institute for Global Change Research (project SGP-CRA \#005, supported by the National Science Foundation, NSF grant no. GEO-1138881), by NSF grant nos. DEB-1010495, FONDECYT grant no. 1110297, as well as European Commission Project MEDIATION, FP7, no. 244012.

Edited by: V. Srinivasan

\section{References}

AEVAL - Agencia de Evaluación y Calidad, Ministerio de la Presidencia: Evaluación de la gestión y funcionamiento de las Confederaciones Hidrográficas, Evaluation of the management and operation of Spanish Water Boards, Evaluation and Quality Agency, Ministry of the Presidency, Madrid, Spain, 2010.

Bauer, C. J.: Results of Chilean water markets: Empirical research since 1990, Water Resour. Res., 40, W09S06, doi:10.1029/2003WR002838, 2004. 
Blanco-Gutiérrez, I., Varela-Ortega, C., and Flichman, G.: Costeffectiveness of water conservation measures: A multi-level analysis with policy implications, Agr. Water Manage., 98, 639-652, 2011.

Blanco-Gutiérrez, I., Varela-Ortega, C., and Purkey, D.: Integrated assessment of policy interventions for promoting sustainable irrigation in semi-arid environments: A hydro-economic modeling approach, J. Environ. Manage., 128, 144-160, 2013.

Case III, H. L., Boles, J., Delgado, A., Nguyen, T., Osugi, D., Barnum, D. A., Decker, D., Steinberg, S., Steinberg, S., Keene, C., White, K., Lupo, T., Gen, S., and Baerenklau, K. A.: Salton Sea ecosystem monitoring and assessment plan, US Geological Survey Open-File Report 2013-1133, US Geological Survey, Reston, Virginia, p. 220, 2013.

CHG - Confederación Hidrográfica del Guadiana: Plan Hidrológico de la parte española de la demarcación hidrográfica del Guadiana, Memoria, Summary of the Guadiana River Basin Management Plan, Guadiana River Basin Authority, Spanish Ministry of the Environment and Rural and Marine Affairs, Badajoz, Spain, 2013.

EC - European Commission: Council Regulation No 1782/2003 of 29 September 2003 establishing common rules for direct support schemes under the common agricultural policy and establishing certain support schemes for farmers, Office for Official Publications of the European Union, Luxemburg, 2003.

EC - European Commission: Council Regulation No 73/2009 of 19 January 2009 establishing common rules for direct support schemes for farmers under the common agricultural policy and establishing certain support schemes for farmers, Office for Official Publications of the European Communities, Luxembourg, 2009.

Falkenmark, M. and Lannerstad, M.: Consumptive water use to feed humanity - curing a blind spot, Hydrol. Earth Syst. Sci., 9, 1528, doi:10.5194/hess-9-15-2005, 2005.

Foster, S. S. D. and Perry, C. J.: Improving groundwater resource accounting in irrigated areas: a prerequisite for promoting sustainable use, Hydrogeol. J., 18, 291-294, 2010.

IID - Imperial Irrigation District: Efficiency Conservation Definite Plan, Final Report, Imperial, California, 2007.

IID - Imperial Irrigation District: Annual Report, Imperial, California, 2009.

INE - Instituto Nacional de Estadística: Censo Agrario, Agricultural Census, Series 1962, 1999, 2009, Spanish National Statistics Institute, Madrid, Spain, 2009.

Jaspers, F. G.: Institutional arrangements for integrated river basin management, Water Policy, 5, 77-90, 2003.

Lankford, B. A.: Fictions, fractions, factorials and fractures; on the framing of irrigation efficiency, Agr. Water Manage., 108, 27-38, 2012.

Lankford, B. A.: Resource Efficiency Complexity and the Commons: The Paracommons and Paradoxes of Natural Resource Losses, Wastes and Wastages, Routledge, 2013.

Lankford, B. A., Merrey, D., Cour, J., and Hepworth, N.: From integrated to expedient: An adaptive framework for river basin management in developing countries, Research Report No. 110, International Water Management Institute, Colombo, Sri Lanka, 2007.
Llamas, M. R. and Martínez-Santos, P.: Significance of the Silent Revolution of intensive groundwater use in world water policy, chapter in: Water Crisis: Myth or Reality, edited by: Rogers, P. P., Llamas, M. R., and Martinez-Cortina, L., Taylor and Francis Plc., London, UK, 163-180, 2006.

López-Gunn, E., Zorrilla, P., Prieto, F., and Llamas, M. R.: Lost in translation? Water efficiency in Spanish agriculture, Agr. Water Manage., 108, 83-95, 2012.

Maganda, C.: Collateral damage: how the San Diego-Imperial Valley water agreement affects the Mexican side of the border, J. Environ. Develop., 14, 486-506, doi:10.1177/1070496505282668, 2005.

MAGRAMA - Ministerio de Agricultura, Alimentación y Medio Ambiente: Anuario de Estadística Agraria. Series anuales 19702011, Agricultural Statistics Yearbook, Annual series from 1970 to 2011, Spanish Ministry of Agriculture, Food, and Environment, Madrid, Spain, 2012.

MAGRAMA - Ministerio de Agricultura, Alimentación y Medio Ambiente: Encuesta sobre superficies y rendimientos de cultivos, Crop areas and yields surveys, Annual series from 2002 to 2012, Spanish Ministry of Agriculture, Food, and Environment, Madrid, Spain, 2013.

Medellín-Azuara, J., Lund, J., and Howitt, R.: Water supply analysis for restoring the Colorado River Delta, Mexico, J. Water Resour. Pl. Manage., 133, 462-471, doi:10.1061/(ASCE)07339496(2007)133:5(462), 2007.

Molden, D., Oweis, T., Steduto, P., Bindraban, P., Hanjra, M. A., and Kijne, J.: Improving agricultural water productivity: between optimism and caution, Agr. Water Manage., 97, 528-535, 2010.

Molle, F. and Wester, P. (Eds.): River basin trajectories: societies, environments and development, CABI, Wallingford, UK, 328 pp., 2009.

Perry, C.: Accounting for water use: Terminology and implications for saving water and increasing production, Agr. Water Manage., 98, 1840-1846, 2011.

Rockström, J.: Resilience building and water demand management for drought mitigation, Phys. Chem. Earth, 28, 869-877, 2003.

Santos Pereira, L., Cordery, I., and Iacovides, I.: Improved indicators of water use performance and productivity for sustainable water conservation and saving, Agr. Water Manage., 108, 39-51, 2012.

Scott, C. A. and Buechler, S. J.: Iterative driver-response dynamics of human-environment interactions in the Arizona-Sonora borderlands, Ecosphere, 4, 1-16, doi:10.1890/ES12-00273.1, 2013.

Scott, C. A., Meza, F. J., Varady, R. J., Tiessen, H., McEvoy, J., Garfin, G. M., Wilder, M., Farfán, L. M., Pineda Pablos, N., and Montaña, E.: Water security and adaptive management in the arid Americas, Ann. Assoc. Am. Geogr., 103, 280-289, doi:10.1080/00045608.2013.754660, 2013.

Ulanowicz, R. E., Goerner, S. J., Lietaer, B., and Gomez, R.: Quantifying sustainability: Resilience, efficiency and the return of information theory, Ecol. Complex., 6, 27-36, 2009.

Varela-Ortega, C.: The water policies in Spain: Balancing water for food and water for nature, chapter in: Water for food: Quantity and quality in a changing world, edited by: Ingram, H. and Garrido, A., Rosenberg International Forum on Water Policy, Routledge, Taylor and Francis Group, Abingdon, UK, 262-308, 2011. 
Varela-Ortega, C., Blanco-Gutiérrez, I., Swartz, C., and Downing, T. E.: Balancing groundwater conservation and rural livelihoods under water and climate uncertainties: an integrated hydroeconomic modeling framework, Global Environ. Change, 21, 604-619, 2011.

Vicuña, S., Garreaud, R. D., and McPhee, J.: Climate change impacts on the hydrology of a snowmelt driven basin in semiarid Chile, Climatic Change, 105, 469-488, 2011.

Vicuña, S., McPhee, J., and Garreaud, R. D.: Agriculture vulnerability to climate change in a snowmelt driven basin in semiarid Chile, J. Water Resour. Pl. Manage., 138, 431-441, 2012.
Ward, F. and Pulido, M.: Water conservation in irrigation can increase water use, P. Natl. Acad. Sci., 105, 18215-18220, 2008.

Whittlesey, N.: Improving irrigation efficiency through technology adoption: When will it conserve water?, chapter in: Water Resources Perspectives: Evaluation, Management and Policy, edited by: Alsharhan, A. S. and Wood, W. W., Elsevier Science, Amsterdam, the Netherlands, 53-62, 2003. 